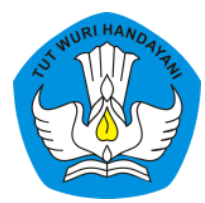

Page: 271-290

\title{
ANALISIS TINGKAT LITERASI DIGITAL DAN KETERAMPILAN KOLABORASI SISWA DALAM PEMBELAJARAN IPA KELAS VII SECARA DARING
}

\author{
Qurrota A'yun \\ Sekolah Menengah Pertama Semesta 2 Semarang, Jawa Tengah, Indonesia \\ Contributor Email: qurota@semestaschool.sch.id
}

Received: Feb 12, 2021

Accepted: Mar 5, 2021

Published: Mar 30, 2021

Article Url: https://ojsdikdas.kemdikbud.go.id/index.php/didaktika/article/view/286

\begin{abstract}
The purpose of this research was to analyze the profile of digital literacy and student collaboration skills in the online science learning on chapter Interaction of Living Things with the Environment. This research was a descriptive qualitative and conducted from October to November 2019. The instruments were a questionnaire and observation sheet. Both instruments are used to measure the level of digital literacy and collaboration skills. The results obtained were that the students' digital literacy levels were divided into three categories, namely high 69\%, medium 18\%, and low 13\%. Meanwhile, the level of student collaboration skills is also divided into three categories, namely high $72 \%$, medium $23 \%$, and low $7 \%$. The indicators and the item questions from the questionnaires and from the observation sheets can be used as a basis for further research. The conclusion of this research is the digital literacy skill and collaborative skill in the high level with the score of questionnaires and observation sheet.
\end{abstract}

Keywords: Digital Literacy; Collaborative Skill; Science Virtual Learning 


\begin{abstract}
Abstrak
Keterampilan belajar dan keterampilan literasi di abad 21 ini yang dibutuhkan siswa adalah keterampilan kolaborasi dan literasi digital. Tujuan dari penelitian ini yaitu untuk menganalisis tingkat literasi digital dan keterampilan kolaborasi siswa dalam pembelajaran IPA secara daring pada topik Interaksi Makhluk Hidup dengan Lingkungannya. Penelitian ini berjenis deskriptif kualitatif dan dilakukan pada Oktober s.d. November 2019. Instrumen yang digunakan adalah angket kuesioner dan lembar observasi. Kedua instrumen tersebut dipakai untuk mengukur tingkat literasi digital dan keterampilan kolaborasi. Hasil penelitian yang diperoleh yaitu tingkat literasi digitial siswa dibedakan menjadi tiga kategori, yaitu tinggi 69\%, sedang 18\%, dan rendah 13\%. Sementara itu, tingkat keterampilan kolaborasi siswa juga dibedakan menjadi tiga kategori yaitu tinggi $72 \%$, sedang 23\%, dan rendah $7 \%$. Indikator dan item pertanyaan dari angket dan lembar observasi ini dapat dijadikan sebagai landasan untuk penelitian selanjutnya. Simpulan dari penelitian ini adalah keterampilan literasi digital dan keterampilan kolaborasi siswa termasuk dalam kategori tinggi melalui skor yang didapat pada angket dan lembar observasi.
\end{abstract}

Kata Kunci: Literasi Digital; Keterampilan Kolaborasi; Pembelajaran IPA Daring

\title{
A. Pendahuluan
}

Di tengah pandemi Covid-19 ini, penggunaan dan pemanfaatan Teknologi Informasi dan Komunikasi (TIK) dalam proses pembelajaran memang sangat diperlukan. Hal tersebut terjadi karena ditiadakannya pembelajaran tatap muka di kelas. Maka dari itu, pembelajaran dalam jaringan (daring) mutlak dilakukan agar peserta didik tetap mendapatkan keterampilan yang harus dimiliki di abad 21 ini. Menurut Kemendikbud, (2019), Bialik \& Fadel, (2015), dan NEA (2012), ada empat macam keterampilan belajar (learning skill) yang harus dimiliki oleh individu di abad 21 ini. Keterampilan tersebut adalah keterampilan berpikir kritis, berpikir kreatif, berkolaborasi, serta berkomunikasi. Selain keterampilan untuk belajar tadi, seseorang juga perlu untuk menguasai literasi dasar yang terdiri atas literasi baca tulis, literasi numerasi, literasi sains, literasi digital, literasi finansial, dan literasi budaya. Keenam jenis literasi ini digerakkan oleh Kemendikbud dalam Gerakan Literasi Nasional (GLN).

Salah satu jenis literasi yang bisa dikembangkan dalam suasana pembelajaran daring ini adalah literasi digital. Pelaksanaan pembelajaran 
daring sebagian besar menggunakan dan memanfaatkan berbagai aplikasi yang sebelumnya jarang digunakan dan bahkan tidak pernah digunakan sama sekali. Oleh karena itu, untuk bisa mengikuti pembelajaran daring di masa pandemi Covid-19 ini, siswa minimal harus mampu memahami dan mampu mengoperasikan beragam aplikasi digital yang digunakan oleh gurunya, seperti aplikasi tatap muka virtual (Zoom, Google Meet), Learning Management System (Google Classroom, Edmodo, Classdojo), kuis online (Quizizz, Kahoot, Edpuzzle), dan platform lainnya. Singkatnya, untuk berhasil mengikuti proses pembelajaran daring ini, setiap siswa diharuskan untuk memiliki keterampilan literasi digital.

Literasi digital dapat dipahami sebagai kemampuan untuk menggunakan media digital untuk mencari dan menyampaikan informasi Tiven, (2018) \& R. Fuchs (2018). Donaldson \& Alker, (2019), menyebutkan bahwa literasi digital merupakan konsep literasi yang relevan dengan teknologi, berkomunikasi, dan keterampilan mengevaluasi informasi de-ngan lebih baik. Menurut Bawden, (2008); Julien, (2018); dan Ng, (2012) literasi digital merupakan suatu keterampilan dalam menggunakan dan memahami penggunaan teknologi informasi dan komunikasi, serta dapat mengakses dan mengevaluasi informasi dari berbagai sumber digital.

Keterampilan seseorang dalam literasi digital juga berperan dalam mengenali, memahami, dan menggunakan aplikasi atau media yang tepat untuk mendukung pembelajaran daring. Hal ini sejalan dengan hasil penelitian dari (Nurjanah, et al., 2017), bahwa literasi digital memiliki hubungan yang signifikan dengan kualitas penggunaan e-resources (korelasi sangat tinggi), artinya literasi digital merupakan faktor yang berpengaruh terhadap penggunaan e-resources. Penelitian dari Akbar dan Anggraeni, (2017), juga menyebutkan yaitu siswa yang memiliki kemampuan literasi digital yang baik akan memiliki keterampilan menulis ilmiah yang lebih baik sehingga mereka memiliki peluang lebih baik untuk lulus. Selain itu, literasi digital juga memungkinkan guru dan dosen untuk menciptakan inovasi pembelajaran yang kreatif, inovatif, dan kontemporer, (Danang, 2017). Oleh karena itu, literasi digital memiliki peran yang vital dalam 
keberhasilan siswa selama mengikuti pembelajaran daring di masa pandemi Covid-19 ini.

Salah satu poin vital dari literasi digital ini adalah akan terciptanya tatanan masyarakat dengan pola pikir dan pandangan yang kritis serta kreatif. Mereka tidak akan mudah termakan oleh isu yang provokatif, (Rianto, 2019), menjadi korban informasi hoaks (Tsaniyah \& Juliana, 2019), atau korban penipuan yang berbasis digital (Fatmawati, 2019). Dengan demikian, kehidupan sosial, budaya, dan politik masyarakat akan cenderung aman dan kondusif. Membangun budaya literasi digital perlu melibatkan peran aktif masyarakat secara bersama-sama. Keberhasilan membangun literasi digital merupakan salah satu indikator pencapaian dalam pendidikan dan kebudayaan (Kemendikbud, 2017).

Selain nilai penting dari literasi digital dalam pembelajaran daring ini, ada satu keterampilan yang sangat erat kaitannya dengan keterampilan abad 21. Keterampilan tersebut ialah keterampilan kolaborasi. Keterampilan kolaborasi menurut Greensten, (2012) ialah keterampilan yang menyiratkan pada kemampuan bekerja sama, berpartisipasi secara aktif dan saling menghargai pendapat. Sementara itu, menurut Le \& Janssen, (2018), keterampilan kolaborasi yakni keterampilan untuk berpartisipasi dalam setiap kegiatan untuk membina hubungan dengan orang lain, saling menghargai hubungan dan kerja tim untuk mencapai tujuan yang sama.

Keterampilan kolaborasi ini juga merupakan salah satu bagian dari kurikulum 2013 yang dalam proses belajar mengajarnya untuk lebih berorientasi ke siswa. Lingkungan pembelajaran kolaboratif menantang siswa untuk mengekspresikan dan mempertahankan posisi mereka, dan menghasilkan ide-ide mereka sendiri berdasarkan refleksi. Mereka dapat berdiskusi untuk menyampaikan ide, bertukar dengan sudut pandang yang berbeda, mencari klarifikasi, dan dapat berpikir tingkat tinggi, seperti menganalisis dan menyelesaikan masalah (Zubaidah, 2016).

Keterampilan kolaborasi siswa dapat dilatih dalam pembelajaran, baik dengan menggunakan media, model, metode, pendekatan, desain dan strategi pembelajaran lainnya. Sebagai contoh, melalui desain pembe- 
lajaran sharing and jumping task, (Verawati et al, 2020) melalui model CinQASE (Hunaida et al., 2018) dan Group Investigation (Raupu, 2019), melalui pembelajaran berbasis proyek (Rahmawati, 2019; Setyowidodo et al., 2020) melalui pendekatan STEM (Latip et al., 2020), melalui media interaktif digital (Gan et al., 2015), melalui metode Consultant Social Science (Kurniawati, 2020), dan melalui penggunaan blog (Kuo et al., 2017).

Salah satu strategi yang dipakai untuk mengobservasi keterampilan kolaborasi dan literasi digital siswa dalam PJJ ini adalah dengan memanfaatkan platform pendukung pembelajaran yang berbasis digital. Platform yang digunakan dalam penelitian ini adalah Google Apps for Education atau GAFE. GAFE dikembangkan oleh perusahaan teknologi Google dengan tujuan membantu pengajar dan siswa dalam berkreasi, berkolaborasi, serta mengembangkan keterampilan digital yang berguna di masa depan. Pihak Google berharap dengan adanya GAFE ini siswa memiliki akses ke keterampilan kolaboratif yang mampu membuka berbagai peluang baru, baik di dalam maupun di luar kelas, serta dapat membantu mereka untuk meraih kesuksesan di dunia yang terus berkembang ini. (Bhat et al., 2018; Gupta \& Pathania, 2021; Lindh \& Nolin, 2016).

Aplikasi GAFE yang fleksibel, aman, dan mudah digunakan, serta gratis dan dirancang khusus untuk pendidikan ini terdiri atas Google Docs, Slides, Sheets, Drive, dan Jamboard. Selain GAFE tadi, beberapa platform pendukung belajar berbasis digital lainnya yang dimanfaatkan untuk mengobservasi keterampilan literasi digital mereka yaitu Google Classroom, Gmail, Google Meet, Zoom, WhatsApp, Canva, dan YouTube.

Topik Interaksi Makhluk Hidup dengan Lingkungan merupakan salah satu topik dalam mata pelajaran IPA kelas VII SMP semester gasal. Topik ini membahas tentang komponen lingkungan (abiotik dan biotik), interaksi makhluk hidup dengan makhluk hidup lain (rantai makanan, jaring-jaring makanan, dan simbiosis), pembagian jenis organisme berdasarkan cara makan (herbivora, karnivora, dan omnivora), serta faktor-faktor penyebab kerusakan lingkungan (faktor alam dan faktor manusia). Topik Interaksi Makhluk Hidup dengan Lingkungan dipilih karena konteks atau 
isi di dalam topik ini dapat memberikan kesempatan yang lebih besar kepada siswa untuk berkolaborasi dan memanfaatkan teknologi digital sebagai ciri khas pembelajaran di abad 21.

Dari pemanfaatan berbagai platform dan media berbasis digital tersebut, diharapkan penelitian ini dapat memberikan informasi tentang profil dan deskripsi dari keterampilan kolaborasi dan literasi digital siswa pada pembelajaran IPA dalam topik pada topik Interaksi Makhluk Hidup dengan Lingkungan selama PJJ ini.

\section{B. Metode}

Penelitian ini berjenis deskriptif kualitatif dan dilakukan pada Okto-ber s.d. November 2019. Subjek penelitian ini adalah seluruh siswa kelas VII SMP Semesta 2 Semarang semester II tahun ajaran 2020/2021 yang terdiri atas dua kelas. Data yang diambil yaitu data keterampilan kolabo-rasi dan data literasi digital siswa secara objektif. Instrumen penelitian yang digunakan dalam penelitian ini dapat dilihat pada Tabel 1.

Tabel 1. Instrumen penelitian yang digunakan

\begin{tabular}{|l|l|l|}
\hline \multicolumn{1}{|c|}{ Jenis data } & \multicolumn{1}{|c|}{ Instrumen } & Diisi oleh \\
\hline $\begin{array}{l}\text { Literasi digital ranah } \\
\text { pengetahuan }\end{array}$ & Angket literasi digital & Siswa \\
\hline $\begin{array}{l}\text { Literasi digital ranah } \\
\text { keterampilan }\end{array}$ & Lembar observasi & Observer \\
\hline Keterampilan kolaborasi & $\begin{array}{l}\text { - Lembar observasi } \\
\text { - Angket }\end{array}$ & $\begin{array}{l}\text { - Observer } \\
\text { - Siswa }\end{array}$ \\
\hline
\end{tabular}

Data dianalisis yang bersumber dari angket literasi (skala likert dan isian singkat) serta dari skor lembar observasi (skala likert). Teknik analisis data meliputi tiga tahap, yaitu reduksi data, penyajian data, dan penarikan kesimpulan (Miles, M.B. \& Huberman, 1994). Deskripsi keterampilan kolaborasi dan literasi digital siswa dikategorikan berdasarkan skor yang diberikan oleh observer. Pedoman pengkategorian keterampilan kolaborasi dan literasi digital siswa dapat dilihat pada Tabel 2. 
Tabel 2. Pedoman pengkategorian keterampilan kolaborasi dan literasi digital siswa, diadaptasi dari Arikunto, (2013)

\begin{tabular}{cc}
\hline Skor $(\mathbf{x})$ & Kategori \\
\hline$x \geq 80$ & Sangat Tinggi \\
$60<x \leq 80$ & Tinggi \\
$40<x \leq 60$ & Sedang \\
$20<x \leq 40$ & Rendah \\
$x \leq 20$ & Sangat Rendah \\
\hline
\end{tabular}

\section{Hasil dan Pembahasan}

\section{Hasil}

Tujuan dari penelitian ini adalah untuk mendeskripsikan tingkat lite-rasi digital siswa dan keterampilan kolaborasi siswa melalui skor yang didapat siswa pada angket dan lembar observasi. Hasil rekap data dari angket literasi digial siswa dapat dilihat pada Tabel 3.

Tabel 3. Hasil rekap data dari angket literasi digital siswa (Indikator dimodifikasi dari (Tiven, 2018)

\begin{tabular}{lcc}
\hline \multicolumn{1}{c}{ Indikator dan Pertanyaan } & \multicolumn{2}{c}{ Skor persentase/ Respons } \\
\cline { 2 - 3 } & \multicolumn{1}{c}{ VII A } & VII B \\
\hline $\begin{array}{l}\text { Indikator 1 : Pengetahuan tentang perangkat keras dan perangkat } \\
\text { lunak }\end{array}$ & \\
$\begin{array}{l}\text { 1. Pengetahuan tentang istilah dan fungsi dari perangkat } \\
\quad \text { keras (hardware) dan perangkat lunak (software) }\end{array}$ & $83 \%$ benar & $80 \%$ benar \\
2. Pengetahuan tentang jenis hardware dan software & $96 \%$ benar & $94 \%$ benar \\
\hline Indikator 2: Pengetahuan tentang penggunaan software atau aplikasi & & \\
1. Pengetahuan tentang jenis browser & $83 \%$ benar & $78 \%$ benar \\
2. Pengetahuan tentang aplikasi pengolah dokumen & $70 \%$ benar & $72 \%$ benar \\
3. Pengetahuan tentang aplikasi desain grafis & $100 \%$ benar & $100 \%$ benar \\
\hline
\end{tabular}




\begin{tabular}{|c|c|c|}
\hline \multirow{2}{*}{ Indikator dan Pertanyaan } & \multicolumn{2}{|c|}{ Skor persentase/Respons } \\
\hline & VII A & VII B \\
\hline \multicolumn{3}{|l|}{ Indikator 3 : Memahami keamanan dalam menggunakan internet } \\
\hline $\begin{array}{l}\text { 1. Frekuensi membagikan atau mengumbar data pribadi } \\
\text { (tanggal lahir, no.telp pribadi atau orangtua, alamat rumah } \\
\text { dan sekolah, nama ibu kandung, nomor rekening, nomor } \\
\text { kartu ATM) di internet untuk tujuan yang tidak penting }\end{array}$ & $\begin{array}{l}90 \% \\
\text { sering } \\
\text { membagikan }\end{array}$ & $\begin{array}{c}92 \% \\
\text { sering } \\
\text { membagikan }\end{array}$ \\
\hline $\begin{array}{l}\text { 2. Frekuensi memperbarui password akun medsos dan } \\
\text { akun email yang kalian miliki? }\end{array}$ & $50 \%$ sering & $46 \%$ sering \\
\hline $\begin{array}{l}\text { 3. Frekuensi membuat sebuah password yang kuat (tidak } \\
\text { mudah ditebak orang lain) }\end{array}$ & $\begin{array}{l}70 \% \text { sering } \\
\text { membuat }\end{array}$ & $\begin{array}{l}60 \% \text { sering } \\
\text { membuat }\end{array}$ \\
\hline 4. Frekuensi mengunduh aplikasi bajakan di internet & $\begin{array}{l}27 \% \text { sering } \\
\text { mengunduh }\end{array}$ & $\begin{array}{l}44 \% \text { sering } \\
\text { mengunduh }\end{array}$ \\
\hline 5. Frekuensi memperbarui antivirus komputer dan hp & $\begin{array}{l}53 \% \text { sering } \\
\text { memperbarui } \\
\text { antivirus }\end{array}$ & $\begin{array}{l}61 \% \text { sering } \\
\text { memperbarui } \\
\text { antivirus }\end{array}$ \\
\hline 6. Frekuensi memback-up data di google drive atau di dropbox & $\begin{array}{l}70 \% \text { sering } \\
\text { memback up }\end{array}$ & $\begin{array}{l}45 \% \text { sering } \\
\text { memback up }\end{array}$ \\
\hline
\end{tabular}

Indikator 4 : Memahami etiket komunikasi dalam dunia digital / internet

1. Frekuensi dalam menggunakan bahasa yang baik dan sopan ketika berkomunikasi di medsos?

2. Frekuensi dalam membagikan informasi yang menyinggung SARA (suku, ras, agama), pornografi, dan kekerasan?

3. Frekuensi dalam membagikan informasi yang belum tentu kebenarannya dan berpotensi hoaks?

4. Frekuensi dalam mencantumkan nama pencipta suatu karya, baik itu tulisan, desain, foto, atau gambar; di dalam tugas-tugas kalian?

$\begin{array}{cc}77 \% \text { sering } & 82 \% \text { sering } \\ \text { menggunakan } & \text { menggunakan } \\ 30 \% \text { sering } & 26 \% \text { sering } \\ \text { membagikan } & \text { membagikan } \\ 30 \% \text { sering } & 26 \% \text { sering } \\ \text { membagikan } & \text { membagikan } \\ 63 \% \text { sering } & 42 \% \text { sering } \\ \text { mencantumkan } & \text { mencantumkan }\end{array}$

Sementara itu, hasil rekap data lembar observasi literasi digital siswa dapat dilihat pada Tabel 4.

\section{Tabel 4. Hasil rekap data lembar observasi literasi digital siswa (Indikator dimodifikasi dari (Tiven, 2018)}

\begin{tabular}{llcc}
\hline \multicolumn{1}{c}{ Pernyataan } & \multicolumn{2}{c}{ Persentase } \\
\cline { 3 - 4 } & \multicolumn{1}{c}{ VII A } & VII B \\
\hline $\begin{array}{l}\text { 1. Kemampuan untuk menggunakan alat (gawai) dan mesin pencari (google) } \\
\text { untuk mencari informasi }\end{array}$ & $84 \%$ & $82 \%$ \\
2. Kemampuan untuk menggunakan alat (aplikasi) dalam membuat konten \\
$\begin{array}{l}\text { orisinil (tugas makalah, video) } \\
\text { Kemampuan untuk menggunakan alat (aplikasi) untuk mempresentasikan } \\
\text { informasi secara jelas dan menarik }\end{array}$ & $86 \%$ & $85 \%$ \\
\hline \multicolumn{1}{c}{ Rerata } & $84 \%$ & $84 \%$ \\
\hline \multicolumn{1}{c}{} \\
\hline
\end{tabular}

Rekap data keterampilan kolaborasi indikator 1 (kolaborasi dalam kelompok) dapat dilihat pada Tabel 5. 
Tabel 5. Rekap data keterampilan kolaborasi siswa indikator 1

\begin{tabular}{|c|c|c|}
\hline \multirow[t]{2}{*}{ Indikator } & \multicolumn{2}{|c|}{$\begin{array}{c}\text { Skor } \\
\text { persentase }\end{array}$} \\
\hline & VII A & VII B \\
\hline \multicolumn{3}{|l|}{ Indikator 1 : Kolaborasi dalam kelompok } \\
\hline 1. Kemudahan dalam memahami materi pelajaran apabila belajar dengan kelompok & $64 \%$ & $73 \%$ \\
\hline 2. Pembagian tugas ketika bekerja berkelompok & $64 \%$ & $73 \%$ \\
\hline $\begin{array}{l}\text { 3. Ketersediaan menerima tanggung jawab dalam pembagian tugas sesuai } \\
\text { bagian masing-masing }\end{array}$ & $78 \%$ & $80 \%$ \\
\hline $\begin{array}{l}\text { 4. Ketersediaan untuk membantu teman satu kelompok yang belum selesau } \\
\text { dalam menyelesaiakan tugasnya }\end{array}$ & $89 \%$ & $85 \%$ \\
\hline 5. Menghargai pendapat teman satu kelompok & $84 \%$ & $87 \%$ \\
\hline 6. Memberikan pendapat atau ide ke kelompok & $87 \%$ & $93 \%$ \\
\hline 7. Menghargai pekerjaan teman satu kelompok (tidak memandang remeh dan & $64 \%$ & $71 \%$ \\
\hline tidak iri terhadap tugas masing-masing) & $85 \%$ & $89 \%$ \\
\hline 8. Merasa malas untuk berkolaborasi dalam kelompok & $64 \%$ & $69 \%$ \\
\hline 9. Berusaha untuk menjadi kelompok yang terbaik & $87 \%$ & $85 \%$ \\
\hline 10. Berlapang dada ketika mendapat teman satu kelompok yang kurang cocok & $75 \%$ & $82 \%$ \\
\hline Rerata skor & $78 \%$ & $81 \%$ \\
\hline
\end{tabular}

Sementara itu, rekap data angket keterampilan kolaborasi indikator 2 dapat dilihat pada Tabel 6 .

Tabel 6. Hasil rekap data angket keterampilan kolaborasi indikator 2

\begin{tabular}{|c|c|c|}
\hline \multirow{2}{*}{ Indikator } & \multicolumn{2}{|c|}{ Respons } \\
\hline & VII A & VII B \\
\hline Indikator 2 : Pengguna & & \\
\hline $\begin{array}{l}\text { 1. Aplikasi apa yang kalian sering gunakan untuk } \\
\text { mengerjakan tugas dengan teman satu kelompok? }\end{array}$ & $\begin{array}{l}\text { Slides, Docs, } \\
\text { Sheet, Canva }\end{array}$ & $\begin{array}{l}\text { Slides, Docs, Sheet, } \\
\text { Canva }\end{array}$ \\
\hline $\begin{array}{l}\text { 2. Aplikasi apa yang kalian sering gunakan untuk } \\
\text { berkomunikasi (chat dan sharing file) dengan } \\
\text { teman satu kelompok? }\end{array}$ & WhatsApp & WhatsApp \\
\hline $\begin{array}{l}\text { 3. Aplikasi apa yang kalian sering gunakan untuk } \\
\text { bertatap muka virtual dengan teman satu kelompok? }\end{array}$ & $\begin{array}{l}\text { Zoom, Whatsapp } \\
\text { Vid call, Meet }\end{array}$ & $\begin{array}{l}\text { Zoom, Whatsapp } \\
\text { Vid call, Meet }\end{array}$ \\
\hline
\end{tabular}

Tabel 7. Hasil rekap data lembar observasi keterampilan kolaborasi siswa (modifikasi dari Greenstein, 2012)

\begin{tabular}{|c|c|c|}
\hline \multirow{2}{*}{ Indikator } & \multicolumn{2}{|c|}{ Persentase } \\
\hline & VII A & VII B \\
\hline $\begin{array}{l}\text { 1. Siswa berkontribusi (membagi tugas, memberikan ide, pendapat, saran) } \\
\text { dalam kelompok secara aktif }\end{array}$ & $80 \%$ & $82 \%$ \\
\hline 2. Siswa menunjukkan tanggung jawab terhadap tugasnya dalam kelompok & $82 \%$ & $84 \%$ \\
\hline $\begin{array}{l}\text { 3. Siswa menunjukkan sikap saling menghargai pendapat dan bagian tugas } \\
\text { masing-masing }\end{array}$ & $80 \%$ & $82 \%$ \\
\hline Rerata & $80 \%$ & $82 \%$ \\
\hline
\end{tabular}




\section{Pembahasan}

\section{a. Deskripsi Literasi Digital Siswa}

1) Pengetahuan tentang perangkat keras dan perangkat lunak

Pada indikator 1 terdapat empat pertanyaan yang mengukur pengetahuan siswa tentang perangkat keras (hardware) dan perangkat lunak (software). Sekitar 80\% siswa di kelas VII A dan VII B mengetahui istilah dan fungsi dari kedua jenis perangkat. Sementara itu, lebih dari 90\% siswa menjawab benar ketika memilih jenis hardware dan software. Sebagian besar dari mereka mengetahui seputar hardware dan software dari pembelajaran IPA, IPS, Bahasa Indonesia dan Bahasa Inggris yang membahas tentang teknologi dan komputer. Secara tidak langsung, mereka familiar dengan istilah, fungsi, dan contoh dari hardware dan software. Namun, ada dua pertanyaan yang cukup membingungkan. Mereka belum begitu paham apakah sebuah komputer bisa bekerja tanpa sebuah hardware dan software atau tidak. Hampir 70\% mereka menjawab tidak bisa bekerja, walaupun sebenarnya komputer bisa bekerja tanpa 'sebuah' hardware dan software. Misalnya, komputer masih bisa bekerja tanpa sebuah hardware seperti mouse atau speaker. Bisa juga tanpa sebuah software seperti antivirus atau software editing video (Filmora, Adobe Premier).

\section{2) Pengetahuan tentang penggunaan software atau aplikasi}

Pada indikator 2, terdapat tujuh pertanyaan yang berkaitan dengan pengetahuan software atau aplikasi digital. Persentase yang menjawab benar dari pertanyaan tentang jenis browser kelas VII A lebih besar $(83 \%)$ daripada kelas VII B (78\%). Siswa kelas VII A yang semuanya merupakan berjenis kelamin laki-laki cenderung lebih suka mengeksplor informasi dan mencoba jenis browser yang bisa mereka unduh. Dari hal itu, mereka memiliki beberapa browser favorit untuk berinternet dibanding dengan kelas VII B. Namun, siswi VII B lebih unggul dalam pengetahuan tentang software pengolah dokumen dan lebih bervariasi untuk jenis software-nya (tidak hanya satu). Siswi VII B yang semuanya berjenis kelamin perempuan ini 
cenderung lebih rapi dalam hal pengetikan dan layout ketika membuat laporan, tugas, dan paper dibanding kelas VII A.

Persentase maksimal yakni $100 \%$ siswa di kedua kelas mengetahui aplikasi dan sotware untuk desain grafis. Mereka sudah familiar dengan Canva dan Adobe Photoshop untuk membuat desain grafis seperti poster, brosur, infografik, dll. Terlebih, tugas sekolah yang mewajibkan mereka untuk membuat poster dan beberapa lomba dengan kategori desain grafis yang kadang diikuti. Media sosial yang digunakan siswa di kedua kelas untuk berbagi informasi didominasi oleh WhatsApp, Instagram, dan sedikit yang menggunakan Twitter dan Facebook. Dari penggunaan media tersebut dapat membantu siswa untuk meningkatkan efektivitas pembelajaran dan kolaborasi (Lokaria, 2018; Prajana, 2017).

\section{3) Memahami keamanan dalam menggunakan internet}

Pada indikator 2 tentang keamanan dalam berinternet ini terdiri atas delapan butir pertanyaan. Hasil yang mengejutkan berupa sekitar 90\% siswa sering membagikan data pribadi di internet. Mereka sebenarnya tahu kalau data pribadi itu adalah privasi yang sangat penting, dalam hal ini data harus dijaga agar tidak dimanfaatkan orang lain untuk melakukan tindakan kriminal. Namun nyatanya mereka kurang memperhatikan hal yang kadang dianggap sepele itu. Di ranah password, rata-rata hanya setengah dari total jumlah siswa di kedua kelas sering memperbarui password mereka. Sementara itu, siswa VII A dan VII B sudah memiliki password yang kuat. Password yang dimaksud ialah password untuk akun media sosial dan akun email. Mereka sudah cukup paham alasan mengapa password harus selalu diperbarui dan dibuat dengan kuat. Alasan yang diungkapkan yaitu agar password tidak mudah ditebak orang lain dan agar akun mereka tetap aman, tidak dibobol dan di-hack orang lain.

Selanjutnya, terkait dengan aplikasi bajakan. Sebanyak 27\% siswa kelas VII A sering mengunduhnya dari internet, lebih kecil dibanding kelas VII B sebesar $44 \%$. Siswa laki-laki lebih teliti untuk memilih dan mengidentifikasi aplikasi yang ada di internet. Mereka sudah cukup paham bagaimana ciri- 
ciri dari sebuah aplikasi bajakan. Ciri-cirinya seperti dapat diperoleh secara gratis, ada crack-nya, dan proses download yang cukup berbelitbelit. Risiko dari aplikasi bajakan yang dapat mengandung virus dan malware ini rupanya sudah diketahui oleh hampir sebagian besar siswa. Oleh karena itu, mereka juga sudah memasang antivirus yang populer seperti Avast, Avira, Norton, dan Smadav. Namun, baru sekitar 50\% siswa di kedua kelas yang memperbarui antivirusnya secara berkala, walaupun mereka tahu risiko virus bisa menyerang apabila antivirusnya usang dan tidak diperbarui secara teratur.

Berikutnya adalah pengetahuan tentang fitur incognito window dan VPN. Lebih banyak siswa kelas VII A yang tahu (65\%) dibanding kelas VII B (50\%). Menurut mereka, fungsi dari fitur incognito window adalah untuk kerahasiaan ketika browsing, sehingga history dan cookies tidak terlacak. Sementara itu, VPN bisa berfungsi untuk mengakses situs yang diblokir oleh pemerintah. Sebagian siswa VII A mengaku pernah memakai ini untuk membuka situs tertentu. Di pertanyaan terakhir, berkaitan dengan back-up data. Sebanyak 70\% siswa VII A sering memback-up data di penyimpanan eksternal maupun yang berbasis cloud seperti Google Drive dan Dropbox. Mereka sudah merasa bahwa data bisa sewaktu-waktu hilang dan harus di back-up agar tidak hilang.

\section{4) Memahami etiket komunikasi secara online}

Beralih ke indikator 4 yaitu memahami etiket komunikasi dalam dunia digital dan di internet. Diketahui sekitar 3/4 dari tiap kelas sering menggunakan bahasa yang baik dan sopan. Mereka belajar etika ini dari topik yang disampaikan guru BK dan wali kelas saat pelajaran bimbingan dan konseling. Mereka beralasan bahwa kepribadian seseorang bisa dilihat dari cara ia berkomunikasi, baik lisan maupun tulisan. Ketika ada informasi yang berkaitan dengan SARA, pornografi, dan kekerasan, hanya sedikit yang sering membagikannya (30\% dan $26 \%$ ). Persentase yang sama juga ada di pertanyaan terkait dengan seberapa sering membagikan informasi 
berpotensi hoaks. Mereka beropini bahwa apabila membagikan informasi hoaks, maka akan menimbulkan keresahan dan pembodohan umum ke masyarakat. Terakhir, sebanyak 63\% siswa kelas VII A sering mencantumkan nama pencipta suatu karya tertentu dibanding kelas VII B (42\%). Yang sering mencantumkan nama berpendapat bahwa hal itu menyangkut copyright seseorang dan sebagai tanda penghormatan kepada penulis.

Sementara itu, dari lembar observasi literasi digital diperoleh data bahwa rata-rata kemampuan literasi digital di kedua kelas memiliki perbedaan yang tipis ( $84 \%$ dan $83.7 \%$ ). Lebih dari $80 \%$ dari total siswa di tiap kelas sudah mampu untuk ( $83 \%$ dan $82 \%)$. Hal ini dibuktikan dengan kemampuan mereka dalam mencari informasi secara spesifik di Google. Contohnya dalam mencari gambar berukuran besar, mereka bisa mengatur di pengaturan pencarian (memilih ukuran besar). Di samping itu, mereka juga mampu untuk membuat tugas makalah, presentasi, dan video dengan menggunakan media yang berbeda. Ada yang menggunakan Google Docs, Slides, KineMaster, dan Canva. secara tidak langsung penggunaan platform tersebut dapat meningkatkan efektivitas dan motivasi belajar pada siswa (Farida, 2019; Nelyano, 2020). Dalam hal mempresentasikan tugas, mereka juga mampu untuk membuat grafik, tabel, dan ilustrasi yang menarik.

\section{5) Deskripsi Keterampilan Kolaborasi Siswa}

Keterampilan kolaborasi siswa diukur dari skor yang didapat berdasarkan lembar observasi dan angket. Angket yang disebar di kedua kelas menunjukkan terdapat perbedaan atau selisih skor sangat tipis, kelas VII A (skor 78\%) dan VII B (81\%). Selisih skor yang cukup mencolok adalah pada aspek ke-5 (menghargai pendapat teman), ke-6 (memberikan pendapat), dan ke-10 (lapang dada), sementara skor di aspek lain hanya memiliki selisih yang tipis.

Sebanyak 93\% siswi kelas VII B mengaku lebih menghargai pendapat teman kelompoknya dibanding kelas VII A (87\%). Di samping itu, para siswi VII B sebanyak 71\% juga lebih sering memberikan pendapat dalam kelompoknya dibanding kelas VII A (64\%). Di aspek ke-10, siswi VII B 
cenderung kurang bisa berlapang dada apabila mendapatkan teman yang kurang cocok untuk dijadikan dalam satu kelompok. Hal itu tidak terjadi di kelas VII A yang merasa biasa saja dan tidak terlalu memikirkan.

Berdasar angket pula, aplikasi yang sering digunakan untuk berkolaborasi adalah Google Slides, Docs, dan Sheet. Berhubung setiap siswa mendapatkan satu unit chromebook sebagai pendukung dalam pembelajaran daring ini, maka platform dari Googlelah yang support untuk mengolah dokumen dan media kolaborasi siswa. Hal ini sesuai dengan penelitian dari (Novalia et al., 2018) yang menyatakan bahwa Google Apps for Education dapat meningkatkan kualitas pembelajaran, termasuk dalam meningkatkan kolaborasi siswa. Selain itu, ada Canva yang cukup sering dipakai untuk membuat poster dan desain lainnya secara kelompok. Di sisi lain, mereka juga membutuhkan media sosial untuk chat dan sharing file. WhatsApp menjadi pilihan utama mereka karena kemudahan dan popularitasnya. Sementara itu, apabila menginginkan pertemuan virtual, mereka lebih suka untuk menggunakan Zoom, WhatsApp video call, dan kadang memakai Google Meet.

Berlanjut ke data hasil dari lembar observasi keterampilan kolaborasi siswa. Secara rata-rata, skor persentase kolaborasi siswa dalam kelompok pada kelas VII A (80\%) lebih kecil dari kelas VII B (82\%). Berdasarkan observasi di tiap grup, mereka berinisiatif sendiri dalam pembagian tugas. Setiap anggota kelompok memiliki bagian tugas masing-masing, misal ada yang berperan sebagai notulen, sebagai desainer, sebagai juru bicara, dsb. Pembagian tugas ini cukup penting sebagai strategi kelompok untuk menyelesaikan tugas yang diberikan. Kuantitas memberikan pendapat atau ide dalam diskusi kelompok lebih rendah juga di kelas VII A daripada VII B. Dalam hal ini, siswi VII B yang semuanya merupakan siswi perempuan dan lebih suka untuk berdiskusi. Secara psikologis, mereka juga suka untuk berbicara lebih banyak dibanding laki-laki.

Tanggung jawab tiap anggota kelompok lebih tinggi di VII B (84\%) daripada VII A (82\%). Siswi VII A lebih cepat menyelesaikan tugas yang 
diberikan, namun tetap ada satu dua yang terlambat. Dalam hal menghargai pendapat teman sekelompok, kelas VII B lebih tinggi (82\%) dibanding kelas VII A (80\%). Hal ini diindikasikan oleh sikap siswa laki-laki yang kadang langsung mengkritik dan menganggap remeh pendapat lain.

\section{Penutup}

Dari penelitian yang telah dilakukan, diperoleh informasi yaitu tingkat literasi digital siswa dibedakan menjadi tiga kategori, yaitu tinggi $69 \%$, sedang $18 \%$, dan rendah $13 \%$. Sementara itu, tingkat keterampilan kolaborasi siswa juga dibedakan menjadi tiga kategori yaitu tinggi $72 \%$, sedang $23 \%$, dan rendah $7 \%$.

Indikator dan pertanyaan dari angket dan lembar observasi literasi digital dan kolaborasi siswa ini dapat dijadikan sebagai landasan untuk penelitian selanjutnya. Saran untuk penelitian yang akan datang adalah peneliti dapat menambahkan dan meneliti variabel lain yang dapat memengaruhi keterampilan literasi dan kolaborasi siswa.

\section{Ucapan Terimakasih}

Peneliti mengucapkan terimakasih kepada kepala sekolah yang telah memberikan izin penelitian, dan kepada para siswa kelas VII SMP Semesta 2 Semarang yang telah berperan sebagai subjek penelitian.

\section{Daftar Referensi}

Akbar, M. F., \& Anggraeni, F. D. (2017). Teknologi Dalam Pendidikan: Literasi Digital dan Self-Directed Learning pada Mahasiswa Skripsi. Indigenous: Jurnal Ilmiah Psikologi, 2(1), 28-38. https://doi.org/10.23917/indigenous.v1i1.4458

Arikunto, S. (2013). Prosedur Penelitian: Suatu Pendekatan Praktik. Jakarta: Rineka Cipta.

Bawden, D. (2008). Origins and Concepts of Digital Literacy. Digital Literacies: Concepts, Policies and Practices, 30(1), 17-32.

Bhat, S., Raju, R., Bikramjit, A., \& D'souza, R. (2018). Leveraging elearning through google classroom: A usability study. Journal of 
Engineering Education Transformations, 31(3), 129-135. https://doi.org/10.16920/jeet/2018/v31i3/120781

Bialik, M., \& Fadel, C. (2015). Skills for the 21st century: What should studenst learn? Center for Curriculum Redesign, May, 1-18.

Danang, P. (2017). Implementasi Literasi Digital Dalam Gerakan Literasi Sekolah. Konferensi Bahasa Dan Sastra (International Conference on Language, Literature, and Teaching) II, 307-308.

Donaldson, C., \& Alker, Z. (2019). Digital Literacy. Journal of Victorian Culture, 24(3), 329-330. https:// doi.org/10.1093/jvcult/vcz026

Farida, E. (2019). Media pembelajaran teknologi digital untuk meningkatan efektivitas belajar siswa pada abad-21. Jurnal Didaktika Pendidikan Dasar, 3(2), 457-476.

Fatmawati, N. I. (2019). Literasi Digital, Mendidik Anak Di Era Digital Bagi Orang Tua Milenial. Madani, 11(2), 119-138.

Gan, B., Menkhoff, T., Smith, R. R., Enhancing, R. R., Gan, B., Menkhoff, T., \& Smith, R. (2015). Institutional Knowledge at Singapore Management University Enhancing students' learning process through interactive digital media: New opportunities for collaborative learning. Computers in Human Behavior, 1(1), 652-663.

Greenstein, L. (2012). Assessing 21st century skills: a guide to evaluating mastery and authentic learning. London : Sage Publications.

Gupta, A., \& Pathania, P. (2021). To study the impact of Google Classroom as a platform of learning and collaboration at the teacher education level. Education and Information Technologies, 26(1), 843-857. https://doi.org/10.1007/s10639-020-10294-1

Hunaidah, H., Susantini, E., Wasis, W., Prahani, B. K., \& Mahdiannur, M. A. (2018). Improving Collaborative Critical Thinking Skills of Physics Education Students through Implementation of CinQASE Learning Model. Journal of Physics: Conference Series, 1108(1), 0-7. https://doi.org/10.1088/1742-6596/1108/1/012101

Julien, H. (2018). Digital Literacy in Theory and Practice. Encyclopedia of Information Science and Technology, Fourth Edition.

Kemendikbud. (2017). Gerakan Literasi Nasional : Materi Pendukung Literasi Digital. Jakarta: Kemendikbud. 
Kemendikbud. (2019). Bahan Ajar Pengenalan Pembelajaran dan Penilaian Kurikulum 2013 (Terintegrasi PPK, Literasi, HOTS, 4Cs). Jakarta : Dirjen GTK Kemendikbud.

Kuo, Y. C., Belland, B. R., \& Kuo, Y. T. (2017). Learning through blogging: Students' Perspectives in collaborative blog enhanced learning communities. Educational Technology and Society, 20(2), 37-50.

Kurniawati, L. (2020). Metode Consultant Social Science dalam Upaya Meningkatkan Kemampuan Kolaborasi dan Komunikasi Siswa. Jurnal Didaktika Pendidikan Dasar, 4(2), 557-580. https://doi.org/10.26811/didaktika.v4i2.146

Latip, A., Andriani, Y., Purnamasari, S., \& Abdurrahman, D. (2020). Integration of educational robotic in STEM learning to promote students' collaborative skill. Journal of Physics: Conference Series, 1663(1). https://doi.org/10.1088/1742-6596/1663/1/012052

Le, Ha; Janssen, J. (2018). Collaborative learning practices: teacher and student perceived obstacles to effective student collaboration. Cambridge Journal of Education, 48(1), 103-122. https://doi.org/10.1080/0305764X.2016.1259389

Lindh, M., \& Nolin, J. (2016). Information We Collect: Surveillance and Privacy in the Implementation of Google Apps for Education. European Educational Research Journal, 15(6), 644-663. https://doi.org/10.1177/1474904116654917

Lokaria, E. (2018). Efektivitas media facebook pada pembelajaran ipa siswa kelas VII SMP Xaverius Lubuklinggau. Prosiding National Conference on Mathematics, Science, and Education (NACOMSE), 1(1), 1-10.

Miles, M.B. \& Huberman, A. M. (1994). Qualitative Data Analysis 2nd Edition. London : Sage Publications.

NEA. (2012). An Educator's Guide to the "Four Cs." Washington D.C.: National Education Association.

Nelyano, A. U. (2020). Peningkatan Minat Belajar Siswa dengan Online Remedial Teaching Menggunakan Google Drive. Jurnal Didaktika Pendidikan Dasar, 4(1), 143-150. https:/ / doi.org/10.26811/didaktika.v4i1.154

Ng, W. (2012). Can We Teach Digital Natives Digital Literacy? Computers E Education, 53(3), 1065-1078. 
Novalia, M., Ismanto, E., Vitrian, V., Darni, R., Alrian, R., \& Herlandi, P. B. (2018). Google Apps for Education (GAFE) Demi Peningkatan Kualitas Pembelajaran Era Digital di SMK Dar-El Hikmah Pekanbaru. Jurnal Pengabdian UntukMu NegeRI, 2(2), 7-11. https://doi.org/10.37859/jpumri.v2i2.1094

Nurjanah, E., Rusmana, A., \& Yanto, A. (2017). Hubungan Literasi Digital dengan Kualitas Penggunaan E-Resources. Lentera Pustaka: Jurnal Kajian Ilmu Perpustakaan, Informasi Dan Kearsipan, 3(2), 117. https://doi.org/10.14710/lenpust.v3i2.16737

Prajana, A. (2017). Pemanfaatan Aplikasi Whatsapp Untuk Media Pembelajaran dalam Lingkungan Uin Ar-Raniry Banda Aceh. Cyberspace: Jurnal Pendidikan Teknologi Informasi, 1(2), 122. https://doi.org/10.22373/cs.v1i2.1980

Rahmawati, A. (2019). Analisis Keterampilan Berkolaborasi Siswa SMA Pada Pembelajaran Berbasis Proyek Daur Ulang Minyak Jelantah. Jurnal Pendidikan Dan Pembelajaran Kimia, 8(2).

Raupu, M. S. (2019). Efektivitas model pembelajaran group investigation berbantuan media DUIT terhadap peningkatan keterampilan kolaborasi peserta didik. Jurnal Didaktika Pendidikan Dasar, 1(2), 591-606.

Rianto, P. (2019). Literasi Digital dan Etika Media Sosial di Era Post-Truth. Interaksi: Jurnal Ilmu Komunikasi, 8(2), 24. https://doi.org/10.14710/interaksi.8.2.24-35

Setyowidodo, I., Jatmiko, B., Susantini, E., Handayani, A. D., \& Pramesti, Y. S. (2020). The role of science project based peer interaction on improving collaborative skills and physical problem solving: A mini review. Journal of Physics: Conference Series, 1521(2). https:// doi.org/10.1088/1742-6596/1521/2/022032

Tiven, B. (2018). Evaluating Global Digital Education: Student Outcomes Framework. New York : Bloomberg Philanthropies and the Organisation for Economic Cooperation and Development.

Tsaniyah, N., \& Juliana, K. A. (2019). Literasi Digital Sebagai Upaya Menangkal Hoaks di Era Disrupsi. Al-Balagh : Jurnal Dakwah dan Komunikasi, 4(1), 121. https://doi.org/10.22515/balagh.v4i1.1555

Verawati, Y., Supriatna, A., Wahyu, W., \& Setiaji, B. (2020). Identification of student's collaborative skills in learning salt hydrolysis through 
sharing and jumping task design. Journal of Physics: Conference Series, 1521(4). https://doi.org/10.1088/1742-6596/1521/4/042058

Zubaidah, S. (2016). Keterampilan abad ke-21: keterampilan yang diajarkan melalui pembelajaran. Prosiding Seminar Nasional Pendidikan STKIP Persada Khatulistiwa Sintang, 1(1), 1-10. 
Vol. 5, No. 1, Maret 2020 